Биков Роман Юрійович кандидат наук з державного управління, доцент кафедри державного управління i місцевого самоврядування, Херсонський національний технічний університет, Бериславське Шосе, 24, м. Херсон, 73008, тел.: (067) 551-67-31, e-mail: r.bykov.morgan@gmail.com, https://orcid.org/00000002-2575-5042

\title{
ОЦІНКА ДЕРЖАВНИХ ПРОГРАМ І ПОЛІТИК В УМОВАХ СУЧАСНОГО ДЕРЖАВНОГО УПРАВЛІННЯ
}

Анотація. Оцінювання процесу реалізації та оцінювання державних програм і політик розглядається як один 3 найважливіших компонентів реформування державного управління. У статті проводиться теоретичний аналіз особливостей оцінки державних програм i політик в умовах сучасного державного управління. Розкривається сутність основних підходів до оцінювання ефективності державних програм і політик, які умовно об'єднано в три напрямки: метод аналізу витрат i вигід, метод аналізу витрат i результативності, метод інтегральної оцінки.

У ході аналізу визначено класифікаційні ознаки оцінювання політики i програм з позиції рівня аналізу; суб'єкта оцінювання; етапів оцінювання політик i програм; цілей і змісту оцінювання. Доведено, що залежно від цілей оцінювання програм може бути використаний той чи інший вид оцінювання. Представлено основні якісні та кількісні методи збору та аналізу даних, що найбільш широко застосовуються при проведенні оціночних досліджень, а саме: контент-аналіз, описова статистика, кластерний аналіз, Case-study, кількісний економічний аналіз, SWOT-аналіз, концептуальне картування, описова статистика, регресійний аналіз, факторний аналіз, кластеризація.

За результатами дослідження запропоновано звернути увагу на інноваційні інструменти вирішення досліджуваного питання, серед яких пропоновано запровадження ключових показників ефективності (KPI - Key Performance Indicators). KPI, у загальному вигляді є кількісними показниками, що мають великий потенціал до зростання застосування, оскільки являють собою соціально сконструйований інструмент. Але, якщо зараз оцінка ефективності державних програм і політик заснована на отриманих результатах, то в процесі застосування KPI необхідно враховувати ресурси, індикатори процесу, що використовуються для отримання результатів, і показники результативності (ефекти, викликані 
результатами). Використання KPI здатне забезпечити значне підвищення результативності та ефективності роботи державних органів влади та їх здатності адаптуватися до змін зовнішнього середовища.

Ключові слова: державне управління, оцінка, програма, політика, ефективність.

Bykov Roman Yuriyovych Candidate of Sciences in State Administration, Department of Public Administration and Local Self-Government of Kherson National Technician University, Beryslavske Shosse, 24, Kherson, 73008, tel.: (067) 551-67-31, e-mail: r.bykov.morgan@gmail.com, https://orcid.org/0000-0002-2575-5042

\title{
EVALUATION OF PUBLIC PROGRAMS AND POLICIES UNDER MODERN PUBLIC ADMINISTRATION
}

\begin{abstract}
Evaluating the implementation process and evaluating government programs and policies is seen as one of the most important components of public administration reform. The article provides a theoretical analysis of the specifics of assessing government programs and policies in the context of modern public administration. The essence of the main approaches to assessing the effectiveness of government programs and policies, which are conventionally combined into three areas: the cost-benefit analysis method, the cost-benefit analysis method, and the integral assessment method, are revealed.

In the course of analyzes identified, the classification criteria for evaluating policies and programs from the standpoint of the level of analysis; were determined subject of assessment; stages of evaluating policies and programs; objectives and content of the assessment. It has been proven that, depending on the goals of program evaluation, one or another type of evaluation can be used. The main qualitative and quantitative methods of collecting and analyzing data are presented, the most widely used in evaluative research, namely: content analysis, descriptive statistics, cluster analysis, Case-study, quantitative economic analysis, SWOT- analysis, conceptual mapping, descriptive statistics, regression analysis, factor analysis, clustering.

Based on the research findings it was proposed to pay attention to innovative tools for solving the issue under research, among which the introduction of key performance indicators (KPI - Key Performance Indicators) was proposed. KPI, in general terms, are quantitative indicators, have great potential for growth in use, since they are a socially constructed tool. But, if now the assessment of the effectiveness of government programs and policies is based on the results obtained, then in the process of applying KPI, it is necessary to take into account resources, process indicators used to obtain results, and performance indicators (effects caused by results). The use of
\end{abstract}


KPI can provide a significant increase in the efficiency and effectiveness of the work of state authorities and their ability to adapt to changes in the external environment.

Keywords: public administration, evaluation, program, policy, efficiency.

Постановка проблеми. Останнім часом у багатьох державах відбувається перетворення системи державного управління, які спрямовані на підвищення ефективності державної політики, що відповідає сучасним потребам суспільства. В процесі перетворень, що відбуваються, впроваджуються нові методи управління, одним з найважливіших серед яких є управління за результатами, що грунтується на оцінці ефективності державної політики і програм у всіх сферах державного регулювання. Схожі процеси відбуваються у Великобританії, США, Франції та інших країнах. Таке становище робить актуальним питання оцінки ефективності програм і державної політики як в зарубіжних країнах, так у вітчизняному просторі державного управління. Процес оцінки стає ключовим на етапі виявлення проблемних елементів системи державного управління i безпосередньо в процесі реформ, в якості одного 3 найважливіших нових впроваджуваних методів, у ході яких визначається достатня і необхідна роль i функції держави, розробляються і впроваджуються найбільш результативні методи державної політики, створюються системи контролю кінцевих результатів діяльності державних інститутів.

Однією з основних причин гострої критики оцінки державних програм i політик виступають серйозні недоліки в діючих методиках обгрунтування ефективності їх реалізації. Узагальнено ці недоліки пов’язані з: існуючою на державному i регіональному рівнях управління практикою надання відповідальним виконавцям державних програм надлишкових повноважень при затвердженні таких методик; використанням нерепрезентативним оцінок ступеня досягнення планових значень цільових індикаторів державних програм; домінування формальних критеріїв оцінки якості управління програмами на відміну від підходів, апробованих у світовій практиці і орієнтованих на змістовний аналіз результатів діяльності; застосування тих алгоритмів розрахунку показників ефективності, що часто призводять до логічно суперечливих результатів оцінки.

Аналіз останніх досліджень i публікацій. Наукові розвідки 3 питання використання механізмів аналізу та оцінки державних програм почалися в США і деяких країнах Свропи та пов'язані з іменами К. Левіна [1], Р. Тайлера [2] та інших. Пізніше теоретичну базу аналізу i оцінки програм в плані розвитку методів, ролі цінностей в оцінюванні, використання результатів оцінки для поліпшення програм розширили наукові праці М. Алкіна [3], Б. Гогвуда і Л. Гана [4], С. Нейджела [5], М. Паттона [6], П. Россі [7], Е. Сачмана [8], Д. Стафлбіма [9], 
Х. Чена [10] та ін.

В Україні тема аналізу і оцінки програм також ставала в центрі наукових дискурсів. На сьогодні є ряд наукових досліджень, присвячених методам оцінки державної політики і програм в різних галузях, практиці їх реалізації, оцінки результативності та обмеженості окремих методологій. Окремі автори публікують наукові праці, які розкривають не тільки питання методології аналізу і оцінки програм, але також присвячені вивченню практичних аспектів оцінювання програм, відповідно до вимог сучасного державного управління в Україні. Зокрема, можна відзначити роботи Ю. Кальниша [11], О. Новакової і Н. Пашиної [12], В.Тертички [13], В. Філіппової [14] та інших.

Однак, на наш погляд, в експертному середовищі сьогодні недостатньо широко розгорнута дискусія про застосування державних програм і про оцінку їх ефективності, що відповідно викликає додаткового дослідження.

У зв’язку з цим метою статті виступає теоретичний аналіз особливостей оцінки державних програм і політик в умовах сучасного державного управління.

Виклад основного матеріалу. В цілому, основні підходи до оцінювання ефективності державних програм і політик можна об'єднати в такі напрямки:

- метод аналізу витрат i вигід, який вимагає оцінки в грошовому еквіваленті всіх витрат і вигід від реалізації політики чи програми;

- $\quad$ метод аналізу витрат і результативності, який не вимагає розрахунку в грошовому вираженні всіх соціальних ефектів, а дозволяє оцінити, скільки коштує одна одиниця результату, причому вартість одиниці результату і $\epsilon$ показником ефективності;

- метод інтегральної оцінки, сутність якого полягає в тому, що напрямкам реалізації програми присвоюються вагові коефіцієнти (основними напрямами інтегральної оцінки є цілі і завдання, планування, управління і моніторинг, результативність і ефективність).

Оцінка реалізації програми «триває протягом усього терміну реалізації програми , i певним чином, є моніторингом і звітом про досягнуті результати програми в порівнянні із запланованими цілями» [15]. Аналіз наукової літератури доводить, що залежно від цілей оцінювання програм може бути використаний той чи інший вид оцінювання. Розглянемо більш детально класифікацію видів оцінки політик и програм, що дають науковці. 
Класифікаційні ознаки оцінювання політики і програм [16]

\begin{tabular}{|c|c|c|c|c|c|c|c|}
\hline \multicolumn{8}{|c|}{ І. Рівень аналіза } \\
\hline \multicolumn{2}{|c|}{ Мікрорівень } & \multicolumn{2}{|c|}{ Мезорівень } & \multicolumn{2}{|c|}{ Макрорівень } & \multicolumn{2}{|r|}{ Метарівень } \\
\hline \multicolumn{2}{|c|}{$\begin{array}{l}\text { Оцінка як обмежена в } \\
\text { часі діяльність, що } \\
\text { спрямована на } \\
\text { створення продукту } \\
\text { (послуги) }\end{array}$} & \multicolumn{2}{|c|}{$\begin{array}{l}\text { Оцінка як сукупності } \\
\text { заходів (дій), } \\
\text { спрямованих на } \\
\text { досягнення } \\
\text { стратегічних і інших } \\
\text { цілей } \\
\end{array}$} & \multicolumn{2}{|c|}{$\begin{array}{l}\text { Оцінка як інструмент } \\
\text { спрямованої діяльності } \\
\text { держави в різних сферах }\end{array}$} & \multicolumn{2}{|c|}{$\begin{array}{l}\text { Мета-оцінювання як } \\
\text { перевірка достатності } \\
\text { використаних прийомів } \\
\text { і методів оцінки для } \\
\text { підсумкового висновку } \\
\text { по об’єкту оцінки } \\
\end{array}$} \\
\hline \multicolumn{8}{|c|}{ II. Суб’єкт оा } \\
\hline \multicolumn{4}{|c|}{ Внутрішне оцінювання } & \multicolumn{4}{|c|}{ Зовнішне оцінювання } \\
\hline \multicolumn{4}{|c|}{$\begin{array}{l}\text { Оцінка співробітниками органу виконавчої } \\
\text { влади, що реалізує програму }\end{array}$} & \multicolumn{4}{|c|}{$\begin{array}{l}\text { Оцінка з боку контролюючих органів або сторонніх } \\
\text { ррганізацій }\end{array}$} \\
\hline \multicolumn{8}{|c|}{ III. Етапи оцінювання політик і програм } \\
\hline \multirow{2}{*}{\multicolumn{2}{|c|}{$\begin{array}{l}\text { Визначення потениіалу } \\
\quad \text { оцінювання }\end{array}$}} & \multicolumn{2}{|c|}{ Попереднє оцінювання } & \multicolumn{2}{|c|}{ Проміжне оцінювання } & \multicolumn{2}{|r|}{$\begin{array}{c}\text { Узагальнююче } \\
\text { оцінювання }\end{array}$} \\
\hline & & $\begin{array}{l}\text { Аналіз } \\
\text { закладє } \\
\text { ідеї до } \\
\text { реаліза } \\
\text { оцінка } \\
\text { витрат, } \\
\text { з метоң } \\
\text { проєкт } \\
\end{array}$ & $\begin{array}{l}\text { сті } \\
\text { проєктної } \\
\text { :iї їі } \\
\text { попередня } \\
\text { енційних } \\
\text { ід і ефектів } \\
\text { ригування } \\
\end{array}$ & \multicolumn{2}{|c|}{$\begin{array}{l}\text { Аналіз в послідовності } \\
\text { реалізованих стадій для } \\
\text { поточного аналізу } \\
\text { резервів збільшення іiі } \\
\text { результативності та } \\
\text { ефективності в процесі } \\
\text { реалізації політик або } \\
\text { програм } \\
\end{array}$} & \multicolumn{2}{|c|}{$\begin{array}{l}\text { Визначення ступеня } \\
\text { досягнення } \\
\text { поставлених цілей, } \\
\text { ступеня впливу на } \\
\text { соціально-економічне } \\
\text { становище реципієнтів } \\
\text { по завершенню }\end{array}$} \\
\hline \multicolumn{8}{|c|}{ IV. Цілі оцінювання } \\
\hline \multicolumn{4}{|c|}{\begin{tabular}{|c|c|} 
Оиінка, орієнтована на Оиінка, орієнтована на \\
виконання завдань & управління \\
\end{tabular}} & \multicolumn{2}{|c|}{$\begin{array}{c}\text { Оиінка, орієнтована на } \\
\text { споживача }\end{array}$} & \multicolumn{2}{|c|}{$\begin{array}{c}\text { Оиінка, орієнтована на } \\
\text { розв'язання } \\
\text { суперечностей } \\
\end{array}$} \\
\hline \multicolumn{2}{|c|}{$\begin{array}{l}\text { Визначення ступеня } \\
\text { виконання завдань, } \\
\text { оцінка результативності } \\
\text { програмних заходів } \\
\end{array}$} & \multicolumn{2}{|c|}{$\begin{array}{l}\text { Оцінка реалізації з } \\
\text { точки зору } \\
\text { оптимізації } \\
\text { управлінських рішень } \\
\end{array}$} & \multicolumn{2}{|c|}{$\begin{array}{l}\text { Оцінка ступеня } \\
\text { досягнення цілей з точки } \\
\text { зору впливу (ефекту) на } \\
\text { реципієнтів } \\
\end{array}$} & \multicolumn{2}{|c|}{$\begin{array}{l}\text { Прогнозна оцінка } \\
\text { альтернативних } \\
\text { варіантів реалізації } \\
\text { політики або програми } \\
\end{array}$} \\
\hline \multicolumn{8}{|c|}{ V. Зміст оцінювання } \\
\hline $\begin{array}{c}\text { Оичінка } \\
\text { потреби в } \\
\text { політмиі або } \\
\text { програмах }\end{array}$ & \multicolumn{2}{|c|}{$\begin{array}{c}\text { Оиінка } \\
\text { потениціалу } \\
\text { реалізації }\end{array}$} & $\begin{array}{l}\text { Оиінка } \\
\text { езультатів }\end{array}$ & $\begin{array}{c}\text { Оиінка } \\
\text { ефективності }\end{array}$ & \multicolumn{2}{|c|}{$\begin{array}{l}\text { Оиінка } \\
\text { продуктив- } \\
\text { ності }\end{array}$} & Ouii \\
\hline $\begin{array}{l}\text { Оцінка } \\
\text { соціально- } \\
\text { економічних } \\
\text { умов, що } \\
\text { зумовили } \\
\text { необххднність } \\
\text { реалізації } \\
\text { політики, } \\
\text { програми }\end{array}$ & \multicolumn{2}{|c|}{$\begin{array}{l}\text { Експертиза } \\
\text { змісту і } \\
\text { ресурсної } \\
\text { забезпеченості } \\
\text { програми з } \\
\text { точки зору } \\
\text { визначення } \\
\text { ступеня } \\
\text { відповідності } \\
\text { фактичної } \\
\text { діяльності з } \\
\text { планами }\end{array}$} & $\begin{array}{l}\text { Визначення } \\
\text { ступеня } \\
\text { досягнення } \\
\text { цільових } \\
\text { показників, } \\
\text { результатів }\end{array}$ & $\begin{array}{l}\text { Зіставлення } \\
\text { результатів і } \\
\text { ресурсного } \\
\text { забезпечення }\end{array}$ & \multicolumn{2}{|c|}{$\begin{array}{l}\text { Вимірювання } \\
\text { позитивних } \\
\text { результатів і } \\
\text { інших благ, } \\
\text { наданих } \\
\text { програмою, в } \\
\text { розрахунку на } \\
\text { одного } \\
\text { реципієнта }\end{array}$} & $\begin{array}{l}\text { Виявлення } \\
\text { причинно- } \\
\text { наслідкових } \\
\text { зв’язків між } \\
\text { параметрами } \\
\text { розвитку та } \\
\text { політикою } \\
\text { (програмними } \\
\text { заходами), оцінка } \\
\text { ступеня впливу } \\
\text { політики, програми } \\
\text { на соціально- } \\
\text { економічний } \\
\text { розвиток території }\end{array}$ \\
\hline
\end{tabular}

Отже, застосування різних видів оцінювання вимагає і різних підходів до 
оцінювання та конкретизації ключових понять оцінювання - «результату» i «результативності», які в англомовній практиці звужуються за допомогою наступних розрізнень $[17 ; 18]$ :

- результат як форма конкретного ефекту від виконаної програми, проведеної політики або бюджетного процесу (outcome); як правило, під цією формою розуміються плановані та / або не плановані наслідки впливу суспільства державних органів - фактичні результати;

- результат у вигляді соціального ефекту - конкретних товарів і послуг, які отримують громадяни від державних (муніципальних) організацій (output);

- результативність / продуктивність / ефективність в цілому (performance) сукупність параметрів, відповідно до яких можна дати оцінку результативності / продуктивності і / або ефективності діяльності державних або муніципальних органів;

- вихідні дані, ресурси (input) - фінансові, людські, матеріальні, ті що використовуються для виробництва товарів і послуг державними органами для громадян;

- непрямі впливу - очікувані і неочікувані - політики / програми на соціальну поведінку цільової групи та інших груп населення (impacts);

- економічна ефективність (efficiency) - співвідношення корисного результату (ефекту) і обсягу використаних або витрачених для цього ресурсів, що виражає ступінь доцільності і раціональності здійснених витрат;

- соціальна ефективність (effectiveness) - вираз того, яким чином ступінь в якій цілі можна вважати досягнутими відповідає ступеню, в якій зроблені витрати можна вважати економічними;

- технічна ефективність (efficacy) - «внутрішня» ефективність програми, що виражає здатність відповідальних за іï проведення і реалізацію державних органів мобілізувати свої ресурси.

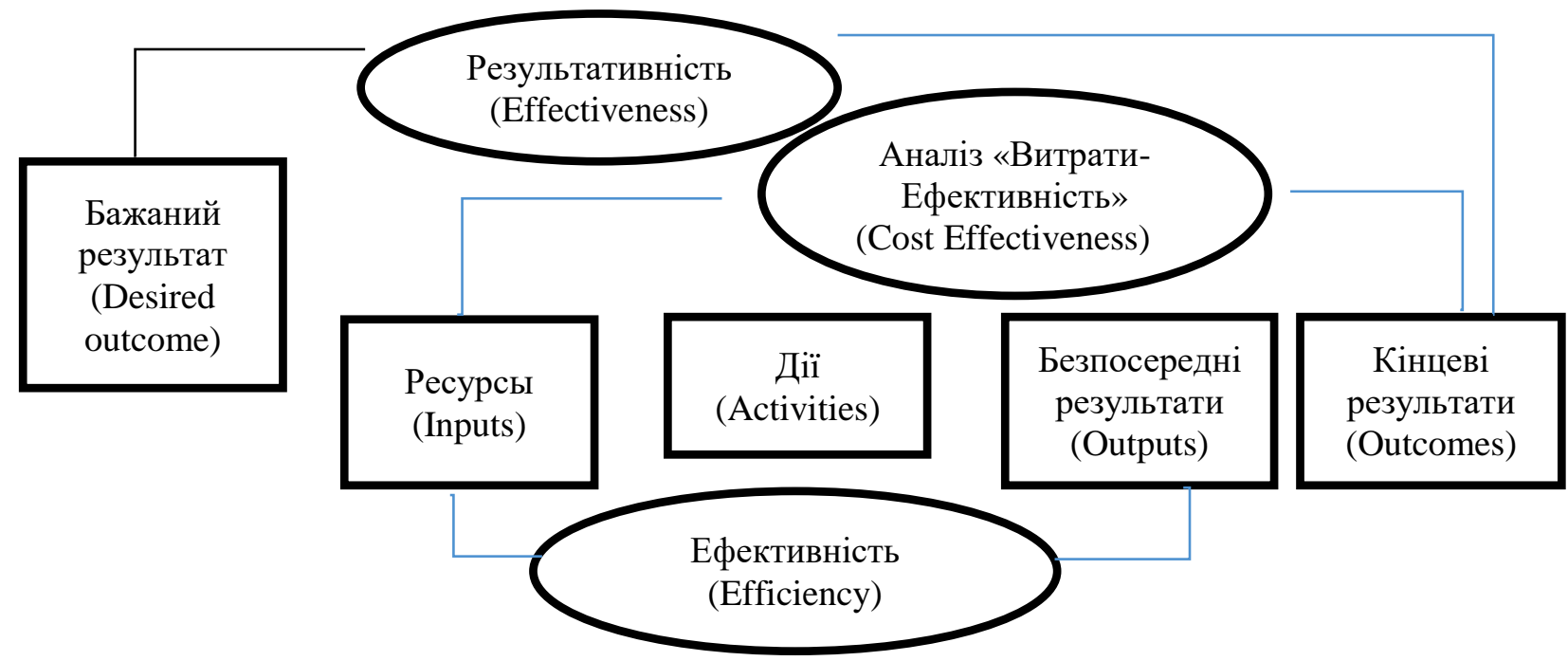

Рис.1. Взаємозвязок компонентів і видів оцінки [18] 
Слід звернути увагу, що в основу оціночних досліджень можуть бути покладено якісні i/або кількісні методи політичного оцінювання. Однак учені зазначають, що основна проблема полягає в тому, що майже всі кількісні методи є також якісними [19]. Основні якісні та кількісні методи збору та аналізу даних, що найбільш широко застосовуються при проведенні оціночних досліджень, представлено нижче, утім варто звернути увагу, що кожен 3 цих напрямків оцінювання може бути доповнений певною кількістю спеціально розроблених оригінальних методів.

1. Аналіз контекстів політичної програми: моніторинг 3МІ, експертні оцінки, експертні опитування. Серед методів аналізу даних варто застосовувати контент-аналіз, описову статистику, кластерний аналіз, Case-study. Це дозволить сформувати релевантні процедурі оцінювання соціальні та експертні «порядку денного», враховувати думку більшості стейкхолдерів;

2. Аналіз сукупних витрат / вигод (за різними вірогідними сценаріями). Серед методів аналізу даних варто застосовувати кількісний економічний аналіз. Це дозволяє додатково визначити сукупні монетизовані витрати i вигоди приватного і / або державного секторів (в залежності від напрямку політики) від «дії» політичної програми, в тому числі за різними вірогідними сценаріями.

3. Структурування оцінки. Серед методів аналізу даних варто застосовувати SWOT-аналіз, концептуальне картування. Це сприятиме виявленню сильних і слабких сторін, альтернативних можливостей і загроз та створенню наочних образів зміни ситуації в контексті політичного втручання.

4. Вибіркове опитування представників «цільової аудиторії» та проведення фокус-груп з ї̈ представниками. Серед методів аналізу даних доцільними будуть: описова статистика, регресійний аналіз, факторний аналіз, кластеризація. Застосування зазначених методів дозволяє виявити реакцію соціальних груп, на поведінку яких вплине реалізація політики/програми, створити «структуру переваг», провести «інвентаризацію» ризиків в тій формі, в якій вони відображаються в масовій свідомості і прогнозувати розвиток ситуації. Отже ми можемо констатувати, що загальновизнаної універсальної методики оцінки ефективності державних програм і політики сьогодні в нашій країні не існує, тому необхідно звернути увагу на інноваційні інструменти вирішення досліджуваного питання, серед яких ми вбачаємо упровадження ключових показників ефективності (KPI - Key Performance Indicators). На нашу думку, використання KPI здатне забезпечити значне підвищення результативності та ефективності роботи державних органів влади та їх здатності адаптуватися до змін зовнішнього середовища.

Виділяються наступні види ключових показників:

- KPI результату - скільки і який результат справили; 
- КРІ витрат - скільки ресурсів було витрачено;

- KPI функціонування - показники виконання (дозволяє оцінити відповідність процесу алгоритму реалізації);

- KPI продуктивності - похідні показники, що характеризують співвідношення між отриманим результатом i часом, витраченим на його отримання;

- KPI ефективності (показники ефективності) - це похідні показники, що характеризують співвідношення отриманого результату до витрат ресурсів.

Тут варто звернути увагу, що при розробці показників процесу необхідно дотримуватися наступних правил: набір показників має містити мінімально необхідну їх кількість для забезпечення повноцінного управління процесом; кожен показник має бути вимірювальним; вартість вимірювання показника не повинна перевищувати управлінський ефект від використання даного показника. Багато вчених відзначають, що KPI, у загальному вигляді $\epsilon$ кількісними показниками, що мають великий потенціал до зростання застосування, оскільки являють собою соціально сконструйований інструмент. Але, якщо зараз оцінка ефективності державних програм і політик заснована на отриманих результатах, то в процесі застосування KPI необхідно враховувати ресурси, індикатори процесу, що використовуються для отримання результатів, i показники результативності (ефекти, викликані результатами).

Висновки. Підводячи підсумок проведеному теоретичному аналізу особливостей оцінки державних програм i політик в умовах сучасного державного управління можна зробити висновок, що на сьогоднішній день немає єдиного підходу і єдиної методики оцінювання. В Україні на сьогоднішній день відбувається поєднання двох основних видів: моніторинг поєднано 3 оцінкою ефективності державних програм / політик. Оцінювання ефективності вимагає упровадження нових інструментів, а саме ключових показників ефективності (KPI - Key Performance Indicators), використання яких вимагає врахування не тільки використовуваних ресурсів (входи), заходів (пропускну здатність), обсягів вироблених товарів (послуг) і досягнутих результатів, а й кількісну та якісну інформацію про динаміку розвитку державного сектора. Саме використання даного інструменту дозволить уніфікувати основні компоненти оцінки результативність, ефективність і проводити ефективний аналіз «витратиефективність».

\section{Лimepamypa:}

1. Lewin K. Action research and minority problems // Journal of Social Issues. 1946. № 2(4). Pp. 34-46.

2. Tyler R. W., Wolf R. M. Crucial issues in testing. Richmond, CA: McCutchan Pub. Corp., 1974. 170 p. 
3. Alkin M. Evaluation roots: tracing theorists' views and influences. Newbury Park, CA : SAGE Publications Inc., 2004. 424 p.

4. Гогвуд Б., Ган Л. Аналіз політики для реального світу / пер. $з$ англ. А. Олійник ; наук. ред. В. Тертичка. К. : Вид-во Соломії Павличко «Основи», 2004. 396 с.

5. Nagel S. Public policy studies. N.Y.: Nova Publishers Inc., 2002. 118 p.

6. Patton M. Utilization-focused evaluation: the new century text. Newbury Park, CA : SAGE Publications Inc., 1997. 431 p.

7. Rossi P. H. Evaluation: A systematic approach. Newbury Park, CA : SAGE Publications Inc., 2004. $480 \mathrm{p}$.

8. Suchman E. A. Evaluative research: principles and practice in public service \& social action programs. N.Y.: Russell Sage Foundation, 1967. 186 p.

9. Stufflebeam D. L., Shinkfield A. J. Evaluation theory, models, and applications. N.Y.: John Wiley and Sons, 2007. 736 p.

10. Chen H.-T. Theory-driven evaluations. Newbury Park, CA : SAGE Publications Inc, 1990. $326 \mathrm{p}$.

11. Кальниш Ю.Г. Політична аналітика в державному управлінні: теоретикометодологічні засади: Моногр. К. : Вид-во НАДУ, 2006. 272 с.

12. Новакова О. В., Пашина Н. П Аналіз державної політики : навчальний посібник. Луганськ : Вид-во СНУ ім. В. Даля, 2013. 216 с.

13. Тертичка В. Державна політика: аналіз та здійснення в Україні. К. : Вид-во Соломії Павличко «Основи», 2002. 750 с.

14. Філіппова В. Д. Адаптація методу когнітивного моделювання до аналізу й оцінки державної політики в галузі педагогічної освіти. Наукові записки Інституту законодавства Верховної Ради України. 2014. №. 6. С. 125-130.

15. GAO. 2011. Government Auditing Standards: 2011 Internet Version. Washington, D.C.: August. URL: http://www.gao.gov/govaud/iv2011gagas.pdf.

16. Данилова И.В., Годовых А.С. Оценивание политик и программ в системе государственного управления регионом: теоретические и методические подходы. Вестник ЮУрГУ. 2013.10 Серия «Экономика и менеджмент». т. 7, № 4, с. 9-19.

17. Posavac E. J. \& Carey R. G. (1985). Program Evaluation: Methods and Case Studies. 2nd ed., Englewood Cliffs, NJ: Prentice-Hall, Inc., 355 pp.

18. Enhancing Program Performance with Logic Models, University of WisconsinExtension, Feb. 2003. URL: http://www.uwex.edu/ces/pdande/evaluation/pdf/lmcourseall.pdf.

19. Kuipers H, Richardson R. Active Qualitative Evaluation: Core Elements And Procedures. Evaluation. 1999; 5(1): 61-79. URL: https://journals.sagepub.com/doi/abs/10.1177/ 13563899922208823\#articleCitationDownloadContainer

\section{References:}

1. Lewin K. Action research and minority problems // Journal of Social Issues. 1946. № 2(4). Pp. 34-46.

2. Tyler R. W., Wolf R. M. Crucial issues in testing. Richmond, CA: McCutchan Pub. Corp., 1974. $170 \mathrm{p}$.

3. Alkin M. Evaluation roots: tracing theorists' views and influences. Newbury Park, CA : SAGE Publications Inc., 2004. 424 p.

4. Hogwood, B., \& Gan, L. (2004). Analiz politiki dlja real'nogo svitu [Policy analysis for 
the real world]. Kiev: VTD Solomiï Pavlichko «Osnovi» [in Ukrainian].

5. Nagel S. Public policy studies. N.Y.: Nova Publishers Inc., 2002. 118 p.

6. Patton M. Utilization-focused evaluation: the new century text. Newbury Park, CA : SAGE Publications Inc., 1997. 431 p.

7. Rossi P. H. Evaluation: A systematic approach. Newbury Park, CA : SAGE Publications Inc., 2004. $480 \mathrm{p}$.

8. Suchman E. A. Evaluative research: principles and practice in public service \& social action programs. N.Y.: Russell Sage Foundation, 1967. 186 p.

9. Stufflebeam D. L., Shinkfield A. J. Evaluation theory, models, and applications. N.Y.: John Wiley and Sons, 2007. 736 p.

10. Chen H.-T. Theory-driven evaluations. Newbury Park, CA : SAGE Publications Inc, 1990. 326 p.

11. Kalnysh, Y.G. (2006). Politichna analitika $v$ derzhavnomu upravlinni: teoretikometodologichni zasadi [Political analytics in public administration: theoretical and methodological principles]. Kiev: VTD NADU [in Ukrainian].

12. Novakova, O.V., \& Pashina, N.P. (2013) Analiz derzhavnoï politiki [Analysis of public policy]. Luhansk: VTD im. V. Dalja Novakova [in Ukrainian].

13. Тертичка В. Державна політика: аналіз та здійснення в Україні. К. : Вид-во Соломії Павличко «Основи», 2002. 750 с.

14. Tertychka, V.(2002). Derzhavna politika: analiz ta zdijsnennja v Ukraïni [Public policy: analysis and implementation in Ukraine]. Kiev: VTD Vid-vo Solomiï Pavlichko «Osnovi» [in Ukrainian].

15. Filippova, V.D. (2014). Adaptacija metodu kognitivnogo modeljuvannja do analizu j ocinki derzhavnoï politiki $\mathrm{v}$ galuzi pedagogichnoï osviti [Adaptation of the method of cognitive modeling to the analysis and evaluation of public policy in the field of pedagogical education]. Naukovi zapiski Institutu zakonodavstva Verhovnoï Radi Ukraïni - Scientific notes of the Institute of Legislation of the Verkhovna Rada of Ukraine, 6, 125-130 [in Ukrainian].

16. GAO. 2011. Government Auditing Standards: 2011 Internet Version. Washington, D.C.: August. URL: http://www.gao.gov/govaud/iv2011gagas.pdf.

17. Danilova, I.V., \& Godovykh, A.S. (2013). Ocenivanie politik i programm v sisteme gosudarstvennogo upravlenija regionom: teoreticheskie i metodicheskie podhody [Evaluation of policies and programs in the system of public administration of the region: theoretical and methodological approaches]. Vestnik JuUrGU. Serija «Jekonomika i menedzhment» - Bulletin of SUSU. Series "Economics and Management", 4, 9-19 [in Russian].

18. Posavac E. J. \& Carey R. G. (1985). Program Evaluation: Methods and Case Studies. 2nd ed., Englewood Cliffs, NJ: Prentice-Hall, Inc., 355 pp.

19. Enhancing Program Performance with Logic Models, University of WisconsinExtension, Feb. 2003. URL: http://www.uwex.edu/ces/pdande/evaluation/pdf/lmcourseall.pdf.

20. Kuipers H, Richardson R. Active Qualitative Evaluation: Core Elements And Procedures. Evaluation. 1999; 5(1): 61-79. URL: https://journals.sagepub.com/doi/abs/10.1177/ 13563899922208823\# articleCitationDownloadContainer 